\title{
Investigation of the Relationship between Temporomandibular Disorder and Postural Analysis
}

\section{Temporomandibular Bozukluk ve Postüral Analiz Arasındaki İlişkinin İncelenmesi}

\author{
Gizem Ergezen ${ }^{1,3}$, Mustafa Sahin $^{2}$ (D, Zeliha Candan Algun ${ }^{3}$ (
}

Istanbul Medipol University, Graduate School of Health Sciences, Physical Therapy and Rehabilitation, Istanbul, Turkey

Istanbul Medipol University, Faculty of Medicine, Department of Orthopedics and Traumatology, Istanbul, Turkey

Istanbul Medipol University, Faculty of Health Sciences, Department of Physiotherapy and Rehabilitation, Istanbul, Turkey
Cite as: Ergezen G, Sahin M, Algun ZC. Investigation of the relationship between temporomandibular disorder and postural analysis. Kocaeli Med J 2021;10(2):27-32

\begin{abstract}
INTRODUCTION: Muscular and ligamentous structures connect the temporomandibular joint (TMJ) to the cervical region to form a functional unit. Changes in one of the two regions, either TMJ or cervical spine, may affect the other region due to changes in the muscle segment. Our aim is to evaluate and compare whether individuals with temporomandibular disorders differ from healthy individuals in the global postural alignment by objective evaluation method.

METHODS: Group $1(\mathrm{~N}=30)$ consist of mixed type temporomandibular disorder (TMD), Group 2 ( $N=30)$ consist of healthy temporomandibular joint, totally 60 individuals between the ages of 18-35 were included in this study. Posture Screen Mobile $($ (PSM) and New York Posture Scale (NYPS) were used for assessment of posture and Research Diagnostic Criteria for Temporomandibular Disorders (RDC/TMD) for diagnosis of TMD and healthy joints.

RESULTS: Knee translations from sagittal plane, were higher in Group $1(\mathrm{p}<0.05)$. No appreciable postural differences were found in other regions $(p \geq 0.05)$. NYPS total scores were significantly lower in Group 1 $(\mathrm{p}<0.05)$.

DISCUSSION AND CONCLUSION: It may be beneficial to consider that some postural disorders can be caused by TMD or that TMD can lead to this posture. Being careful about postural alignment in these patients may be important in terms of multidisciplinary approach to TMD patients for proper treatment program and prevention of possible disorders.
\end{abstract}

Keywords: posture, physiotherapy, TMD

Öz

GİISS ve AMAÇ: Kas ve ligamentöz yapılar temporomandibular eklemi (TME) servikal bölgeye bağlayarak fonksiyonel bir birim oluşturur. İki bölgeden birinde, TME veya servikal omurgada meydana gelen değişiklikler, kas segmentindeki değişiklikler nedeniyle diğer bölgeyi etkileyebilir. Amacımız, temporomandibular bozukluğu olan bireylerin global postural dizilimde sağlıklı bireylerden bir farklılık gösterip göstermediğini objektif değerlendirme methodu ile değerlendirip karşılaştırmaktır.

YÖNTEM ve GEREÇLER: Grup $1(\mathrm{~N}=30)$ mixed tip temporomandibular bozukluktan (TMD), Grup 2 (N = 30) sağlıklı temporomandibular eklemden oluşmakta olup, 18-35 yaşları arasında toplam 60 kişi çalışmaya alındı. Postürü değerlendirmek için PostureScreen Mobile ${ }^{\circledR}$ (PSM) ve New York Postür Skalası (NYPS), sağlıklı eklem ve temporomandibular disfonksiyon tanısı için ise Temporomandibular BozukluklardaAraştırma Teşhis Kriterleri (RDC / TMD) kullanıldı.

BULGULAR: Sagital düzlemde diz translasyonu Grup 1'de daha yüksekti ( $\mathrm{p}<0,05)$. Diğer bölgelerde anlamlı postüral farklılıklar bulunmadı ( $\mathrm{p} \geq 0,05)$. NYPS toplam skorları Grup 1'de anlamlı olarak düşüktü $(\mathrm{p}<0,05)$.

TARTIŞMA ve SONUÇ: Bu postural bozuklukların TMD'den kaynaklanabileceğini veya TMD'nin bu duruşa yol açabileceğini düşünmek yararlı olabilir. Bu hastalarda postüral dizilim konusunda dikkatli olmak, uygun tedavi programı ve olası bozuklukların önlenmesi için TMD hastalarına multidisipliner yaklaşım açısından önemli olabilir.
Geliş tarihi / Received:

03.03.2020

Kabul tarihi / Accepted:

21.06.2021

Sorumlu Yazar/Corresponding Author: Gizem Ergezen

Istanbul Medipol University, Institute of Health Sciences, Department of Physiotherapy and Rehabilitation, Istanbul, Turkey gergezen@medipol.edu.tr ORCID: 0000-0002-2851-9774

M. Sahin 0000-0002-5792-5755 Z.C. Algun 0000-0002-2476-6567

Anahtar Kelimeler: postür, fizyoterapi, TMD 


\section{INTRODUCTION}

Temporomandibular disorder (TMD) is a subgroup of orofacial disorders including temporomandibular joint (TMJ) pain, craniocervical muscle fatigue, especially seen in masticatory muscles, limitation of mandibular motion, presence of clicking and deviation during jaw movements. The etiology of TMD has multifactorial causes such as anxiety, stress, bruxism, changes in the occlusion and postural changes, dysfunctions of the masticatory musculature and adjacent structures and/or a combination of such factors $(1,2)$. Patients with TMD have shown common pain in the areas of facial, neck and shoulder, back and on temporomandibular joints. However, sounds and stiffness of TMJ is also seen $(3,4)$.

The muscular and ligamentous structures connect the temporomandibular joint to the cervical region to form a functional unit (5) where cervical vertebrae and atlantooccipital joint movements simultaneously with jaw movement activation (6). Changes in one of the two regions, either TMJ or cervical spine, may affect the other region due to changes in the muscle segment, may cause elongation or shortening in adjacent muscles that cause tensions in the muscle chain (7). Cervical spine's degenerative changes were found related with active craniocervical trigger points caused by altered head postures in TMD (8). Number of studies show that individuals with TMD have changes in head and cranio-cervical posture (911). However, other studies find no postural link (12-14). Some of the studies have used only craniocervical $(1,11,13,15)$ and some have used global postural evaluation (16-19) methods. The outcomes of the studies using global posture evaluation showed different results as like; no differences (18) and differences in pelvis (16), shoulder (19), head and thoracic curve (17). TMDs and postural changes are still controversial and unclear (20).

Our aim was to examine whether individuals with temporomandibular disorder have a difference on the global posture by comparing it with the healthy control group with objective assessment method of posture.

\section{METHODS}

Study design

The study was designed as a prospective observational, single blinded randomized clinical trial. Present study was conducted in Istanbul between December 2018 and March 2019. The trial received institutional review board approval at University Hospital in accordance with the Declaration of Helsinki and all patients were provided informed consent (Decision no. 119). Outpatient diagnosis was made by a specialist dentist with or without temporomandibular dysfunction and was referred to a physiotherapist for evaluation. The physiotherapist was blinded in terms of participants with and without TMD diagnosis.

Exclusion criteria were: history of trauma, anatomic deformities, skeletal system fractures, diagnosed with rheumatologic or orthopedic diseases, accompanying jaw diagnoses, previous TMD treatment over 6 months before this assessment, pregnancy, have a history of any kind of operation and painful knee, back, neck conditions that may alter the postural assessment. The patient's disorders were clinically diagnosed by physical examination and 31 questions with Research Diagnostic Criteria for Temporomandibular Disorders (RDC/TMD) axis-I and had ongoing complaints for 6 months by the dentist.

A power analysis program (G*Power, ver. 3.1., Universitat Dusseldorf, Dusseldorf, Germany) was used to calculate the sample size $(21,22)$. The effect was calculated according to the mean and standard deviation of the result of a previous study similar to our study (23). Based on 5\% type 1 error, $95 \%$ power and 0.903 effect size to detect was at least the required sample size for each group was 28. Due to the possibility of patient loss, the groups were adjusted to include 30 patients in each group. In the study, 246 subjects were evaluated for temporomandibular joint and randomly who had mix temporomandibular disorder and completely healthy TMJ was included. Based on the principle of volunteerism, group $1(\mathrm{~N}=30)$ consist of mixed temporomandibular disorder, group $2(\mathrm{~N}=30)$ consist of healthy TMJs as the control group, totally 60 individuals between the ages of 18-35 were included in this study.

Each 60 subject completed the informed consent form and questionnaires on the first day prior to participation in the study. Subsequently, postural analysis was carried out. Participant Diagnosis Form and Research Diagnostic Criteria for Temporomandibular Disorders form was filled in for all participants.

\section{Outcome measures \\ Postural analysis}

Posture Screen Mobile ${ }^{\circledR}$ (PSM) (PostureCo Inc., Trinity, $F L, U S A)$ mobile application and the New York Posture Scale (NYPS) were both used for postural evaluation. The posturescreen mobile application has demonstrated strong rater reliability and preliminary evidence of construct validity (24). Reliability of the NYPS has been reported for intra- (0.86) and inter-rater (0.92) reliability of forward head posture (25). An acceptable method error coefficient of $1.9 \%$ was reported for the test-retest reliability for the posture scale. (26).

\section{Posture Screen Mobile}

Measurements were made by licensed physiotherapist using the PSM application downloaded on mobile phone (iPhone; Apple Inc., USA) to 60 individuals. Prior to each evaluation, room was arranged in a standard manner to ensure uniform conditions throughout the test. Two lines perpendicular to each other was taken over the place to determine where individuals should stand during postural assessment. The phone was placed on a stand with 1.5 meters high from the ground and 3 meters from the object standing lines to standardize the viewing angle. 
In order to reduce external factors affecting postural alignment, subjects were asked to stay in minimal clothing and stand barefoot in a comfortable position and avoid strenuous physical activity before assessment. Anatomical reference points for postural analysis were palpated by physiotherapist and marked on the skin with self-adhesive tape by a blinded examiner as to which group the subject belonged to. Then four-sided photos were taken from anterior, posterior and lateral views. Photograph using anterior view, PSM asked the examiner to mark the right pupil of the eye by zoom and the system directs the left pupil to mark in the same zoom and horizontal line occurs. This line calculates right and left head tilt. Then the application asks to mark the upper lip, episternal notch and acromioclavicular (AC) joints that occur in another line. Examiner asked to mark right and left T8 level borders of ribcage, right and left spina iliaca anterior superior (SIAS) on both sides and lastly center of both ankles. Photographs using lateral views, ask to mark tragus, $\mathrm{AC}$ joint, greater trochanter, center of knee joint and lateral malleolus. Photographs using posterior views ask to mark bottom earlobe, spinous process of $\mathrm{C} 7$, right and left acromions, spinous process of T4, T8 level ribcage, T8, T12, L3 vertebrae's spinous processes and both spina iliaca posterior superior (SIPS).

Postural deviation includes measurements, in centimeters, of the horizontal displacement of the head, shoulders, and a lower segment of the hips relative to the body part. For example, head shift is based on the episternal notch; shoulder shift, based on the center of the rib cage line; and hip shift was measured with reference to the center of the line between the two ankles. Frontal plane measurements also included the inclination of the head, shoulders, and hips in degrees relative to the main horizontal. Postural deviations of the same regions were also measured in the sagittal plane. Therefore, sagittal deviations refer to the AC joint as head shift; based on SIAS shoulder shift, hip shift relative to knee, and knee shift relative to the lateral malleolus of the ankle were measured. PSM program software calculated 40 different numerical data postural aspects by using special algorithms such as angulation and translation on photographs (Fig 1).

\section{New York Posture Scale}

New York Posture Scale applies a quantitative approach to evaluate the misalignment of various body parts in anatomic location. For each of the 13 body parts contributing to the overall postural adjustment, it contains sets of three diagrams and short verbal descriptions (27). In the original version of NYPS, for each body segment are given respectively no deviation, slight deviation and sharp deviation and after all total score calculated. Total score is between 18-90 points. Higher the points indicate better the postural alignment (28). Participants were asked to stay in a comfortable, neutral position. NYPS was assessed at the same location, on the same day and same uniform conditions following the evaluation of the Posture Screen Mobile application.

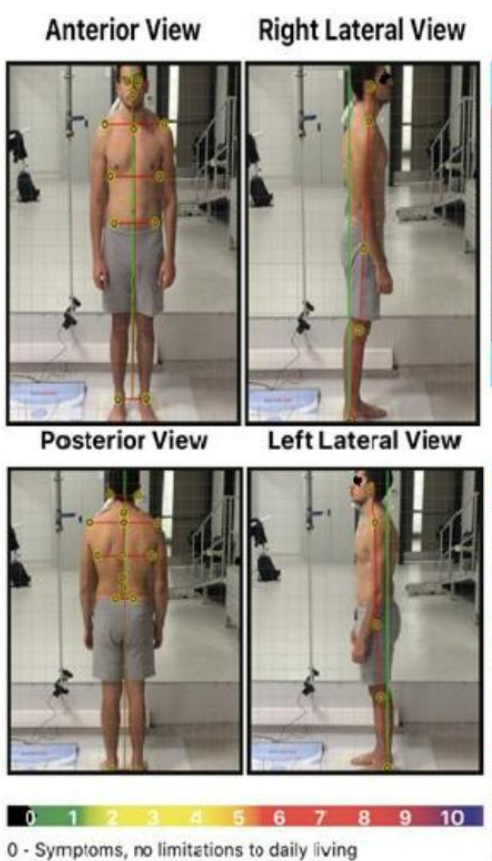

Es:imated Effective Head Weiçht secondary to head vs. shoulder posture is $10.6 \mathrm{kgs}$ instead of $5.8 \mathrm{kgs}$

Figure 1. Output sample of posture analysis made with Posture Screen Mobile.

\section{Research Diagnostic Criteria for \\ Temporomandibular Disorders}

RDC/TMD standardized evaluation and diagnostic criteria which provides criteria for dual axis diagnosis consisting of two parts as 31 question anamnesis and 11 question examination form. Axis-I evaluate physical diagnosis, Axis-II to evaluate the psychometric properties of TMD (29). As a result of the answers to the axis-I questions, one or more of the disease diagnoses collected in 3 different groups can be diagnosed or not. Group I is classified as Myofascial Pain Disorder, Group II Temporomandibular Joint Disc Displacement Disorder, and Group III Temporomandibular Joint Degenerative Disorder and axis-II comprises a psychosocial assessment (30).

The anamnesis form (A) consists of 31 questions and the examination form consists of 11 questions. In this study, the Turkish version of RDC / TMD, which we accessed from the RDC / TMD consortium's website, was used (31).

\section{Data Analysis}

All statistical analyses were completed using "Statistical Package for Social Sciences" (SPSS) Version 22.0 (SPSS Inc. Chicago, $I L, A B D)$. Descriptive statistics in the form of means, standard deviations and counts were used to describe baseline characteristics across study and control groups. Normality was assessed using the Shapiro-Wilk test. Significance was set a priori at an alpha value of 0,05 . Data comparison analysis of independent and parametric data of NYPS total point and PostureScreen Mobile was used "Independent Sample T-Test". 


\section{RESULTS}

Sample Characteristics

Thirty individuals (22 female, 8 male) with mixed (myofascial and arthralgic) TMD and thirty (25 female, 5 male) age and sexmatched healthy controls were assessed. There are no statistic differences between groups in the line of demographics as age, height, weight, body mass index (BMI) and sex ( $\mathrm{p} \geq 0.05)$ (Table 1).

Table 1. Characteristics of the groups

\begin{tabular}{lccc}
\hline & $\begin{array}{c}\text { Group 1 } \\
\mathbf{M} \pm \mathbf{S D}\end{array}$ & $\begin{array}{c}\text { Group 2 } \\
\mathbf{M} \pm \mathbf{S D}\end{array}$ & p-value \\
\hline Age (N=30) & $23.83 \pm 4.60$ & $21.46 \pm 2.50$ & 0.460 \\
Height (N=30) & $167.83 \pm 8.49$ & $167.83 \pm 6.61$ & 0.976 \\
Weight (N=30) & $62.80 \pm 10.87$ & $56.90 \pm 8.52$ & 0.123 \\
BMI (N=30) & $22.19 \pm 2.80$ & $20.15 \pm 2.42$ & 0.104 \\
Sex & $\mathbf{\%}(\mathbf{N})$ & $\%(\mathbf{N})$ & \\
Female & $73.3(23)$ & $83.33(25)$ & 0.167 \\
Male & $26.7(7)$ & $16.67(5)$ & \\
\hline
\end{tabular}

$\boldsymbol{B M I}=$ Body Mass Index, $\boldsymbol{M}=$ Mean Value, $\boldsymbol{S D}=$ Standard Deviation

Table 2. Characteristic postural translation of the participants from anterior, posterior and lateral sides.

\begin{tabular}{|c|c|c|c|}
\hline & $\begin{array}{c}\text { Group } 1 \\
\mathrm{M} \pm \mathrm{SD}(\mathrm{cm})\end{array}$ & $\begin{array}{c}\text { Group } 2 \\
\mathrm{M} \pm \mathrm{SD}(\mathrm{cm})\end{array}$ & p-value \\
\hline \multicolumn{4}{|c|}{ Anterior Side } \\
\hline Head & $2.67 \pm 3.06$ & $2.92 \pm 1.65$ & 0.16 \\
\hline Shoulder & $1.98 \pm 1.82$ & $1.63 \pm 1.63$ & 0.45 \\
\hline Hip & $1.22 \pm 1.65$ & $1.48 \pm 1.21$ & 0.20 \\
\hline \multicolumn{4}{|c|}{ Posterior Side } \\
\hline Head & $1.18 \pm 1.28$ & $1.32 \pm 1.49$ & 0.79 \\
\hline Shoulder & $1.59 \pm 1.55$ & $1.69 \pm 1.49$ & 0.83 \\
\hline Hip & $1.63 \pm 1.24$ & $1.63 \pm 2.18$ & 0.42 \\
\hline $\mathrm{T} 1-\mathrm{T} 4$ & $2.02 \pm 1.66$ & $1.19 \pm 1.35$ & 0.55 \\
\hline T4-T8 & $1.10 \pm 0.98$ & $0.93 \pm 0.80$ & 0.19 \\
\hline T8-T12 & $1.86 \pm 1.43$ & $1.48 \pm 1.24$ & 0.89 \\
\hline T12-L3 & $1.81 \pm 1.71$ & $2.24 \pm 1.37$ & 0.16 \\
\hline L3-SIPS & $2.99 \pm 2.58$ & $3.08 \pm 2.23$ & 0.14 \\
\hline \multicolumn{4}{|c|}{ Lateral Side } \\
\hline R Head & $10.87 \pm 5.46$ & $10.91 \pm 5.08$ & 0.31 \\
\hline L Head & $10.33 \pm 6.12$ & $9.52 \pm 5.40$ & 0.67 \\
\hline R Shoulder & $1.77 \pm 1.76$ & $1.84 \pm 1.51$ & 0.81 \\
\hline L Shoulder & $2.41 \pm 1.95$ & $2.59 \pm 2.19$ & 0.83 \\
\hline R Hip & $3.62 \pm 3.12$ & $3.53 \pm 2.80$ & 0.92 \\
\hline L Hip & $5.24 \pm 4.24$ & $4.19 \pm 2.67$ & 0.49 \\
\hline R Knee & $4.04 \pm 2.14$ & $5.27 \pm 2.73$ & 0.04 \\
\hline L Knee & $4.39 \pm 2.47$ & $6.24 \pm 2.33$ & 0.00 \\
\hline
\end{tabular}

$\mathbf{S I P S}=$ Spina Iliaca Posterior Superior, $\boldsymbol{M}=$ Mean Value, $\boldsymbol{S D}=$ Standard Deviation, $\boldsymbol{R}=$ Right, $\boldsymbol{L}=$ Left

\section{Postural Assessments}

Characteristic postural deviation of the participants from anterior, posterior and lateral sides assessed by PSM, are shown in Table 2. Group 1, in the line of right and left knee translation from the sagittal plane, were shown to have higher values than group $2(\mathrm{p}<0.05)$. No appreciable differences were found in other data sets ( $\mathrm{p} \geq 0.05$ ) (Table 2 ).

There is a statistically difference between the total scores of the results obtained with the other posture assessment method NYPS, calculated total points according to the degree of postural deviation $(\mathrm{p}<0.05)$. Group 1 has the total score as $47.03 \pm 7.35$ $(\mathrm{M} \pm \mathrm{SD})$ and group 2 has $55.17 \pm 4.94$. Scores were significantly lower in group 1 than group $2(\mathrm{p}=0.014)$.

\section{DISCUSSION}

The main purpose of this study was to evaluate and associate the presence of temporomandibular disorder with postural deviations across the whole body. Other studies have expressed a relationship between postural misalignments in TMD and many studies have only investigated the cervical region, but there are not many studies focused on objective quantitative postural assessment methods for the global body. According to the systematic analysis, level of evidence was not reached in terms of the relationship between TMD and whole-body posture misalignment (32). We have designed this study in order to contribute to the literature.

Our results demonstrated that there are no postural disorders in terms of region but also there is a significant difference of their total score for global posture between control and study group. While different results are revealed in studies that examine posture change regionally, it is seen that these studies did not use scales that globally evaluate postural deterioration $(7,12,17$, $33,34,37)$. Considering that the posture is disrupted not only from a single region but as a kinetic chain, we may have seen a postural chain that gradually worsens in general rather than a settled postural disorder in our fairly young participants. In line with this result, we think that we can provide a global evaluation of posture and taking precautions against possible disorders in clinics. In order to prevent postural impairment in individuals diagnosed with TMD and to prevent TMD development in individuals with postural disorders, individuals may be directed to postural exercises in order to increase their quality of life and functionality.

When assessing craniocervical posture, Câmara-Souza et al. (12) found no relationship considered by the positioning of the hyoid bone, head rotation, and the extension/flexion of the head, all TMD participants were diagnosed by RDC/TMD and mixed in terms of subgroups of TMD. Iunes et al. (32) revealed that head and cervical spine posture which assessed by photography did not differ between the groups with a diagnosis of myofascial dysfunction group, mixed TMD group and without TMD group. Uritani et al. (34) observed neck inclination angle were 
significantly lower in TMD group while angle of shoulder, cranial rotation angle and the neck-length/shoulder-width ratio showed no difference. Our results revealed that head and cervical posture from four sides has no difference neither subject nor control groups despite having misalignments in both groups. Such findings make us think some degree of asymmetry occurs due to the dominant side $(35,36)$.

Saito et al. (17) used X-Ray imaging for TMD diagnosis and photographic record for global postural assessment for 10 patients and found out lumbar hyper lordosis and thoracic spine rectification in TMD group. Based on photographic assessment of postural evaluation, Munhoz and Marques (7) recorded no difference of spinal curve posture according to having TMD. Parallel to this study we found no statistically difference of spinal misalignment between groups.

There is no consensus in the literature, while some findings $(16,23)$ are in contrast with our hip posture findings, some of parallel (7). Zonnenberg et al. (16) used criteria of American Academy of Orofacial Pain for diagnosis of TMD and included 40 patients to their study. Photographic postural measurement has been done and established an increased pelvic tilt in TMD group. This difference in our work suggests that the PSM application's translation and comprehension calculations may be based on a sub-segment rather than a reference line since the knee findings showed difference.

In the present study, it was also found that the individuals with TMD presented a greater degree of posture deviations in the knee. There are no studies in the literature with which these findings can be compared. However, Bonato et al. (38) studied the presence of pain in joints and found out those individuals with TMD show high prevalence of pain complaints especially in knee joints.

Regarding total scores of New York Posture Scale, we are able to say that TMD group had lower scores than those who had healthy temporomandibular joints which means worse posture TMD group has. As a result, all individuals independent from TMD showed postural misalignment in various degrees. The great variability in the postural alignment may occur due to daily living habits like sedentary lifestyle, amount of working time and emotional factors. At the same time, it may result from the photographic analysis that based on computerized substructure, showed slight error. Thus, based on the results observed in this study, no direct relationship could be determined between the presence of TMD and the assessed variables, even though statistically significant differences have been found in one of them. Based on data in the current study, TMD seems to be related to whole body posture. It is not possible to conclude whether TMD is the result of a postural misalignment or a cause.

In conclusion, a statistically significant difference was found in terms of knee posture and total score of postural assessment. It may be beneficial to consider that these postural disorders can be caused by TMD or that TMD can lead to this posture. Giving importance to postural alignment in these patients may be important for multidisciplinary approach to patients with TMD for appropriate treatment programs and prevention.

\section{Limitations}

People with temporomandibular dysfunction could not be divided into groups regarding subtypes, postural analysis in subtypes could show better results.

\section{Acknowledgments}

We wish to thank those who guided partly in this research, Dr. Hanefi Kurt in our research.

ClinicalTrials Registry: Clinical Trial Number: NCT03490643.

Ethics Committee Approval: Istanbul Medipol University NonInvasive Clinical Research Ethics Committee (22.03.2017 / 119)

Conflict of Interest: The authors declare no conflict of interests. Funding: There is no funding for this study.

Informed Consent: Written consent to study participation was obtained.

\section{REFERENCES}

1. VisscherCM, Boer WDE, Lobbezoo F, Habets LLMH. Is there a relationship between head posture and crandiomandibular pain? J Oral Rehabil. 2002; 29(11):1030-1036. https://doi.org/10.1046/j.1365-2842.2002.00998.x

2. LeResche L, Saunders K, Von Korff MR, Barlow W, Dworkin SF. Use of exogenous hormones and risk of temporomandibular disorder pain. Pain. 1997; 69(1-2):153-60. https://doi.org/10.1016/S0304-3959(96)03230-7

3. Nomura K, Vitti M, de Oliveira AS, Chaves TC, Semprini $\mathrm{M}$, siéssere $\mathrm{S}$, et al. Use of the fonseca's questionnaire to assess the prevalence and severity of temporomandibular disorders in brazilian dental undergraduates. Braz Dent J. 2007; 18(2):163-7. https://doi.org/10.1590/S0103-64402007000200015

4. Valentić-peruzović M. Temporomandibular DisordersProblems in Diagnostic. 2010; 2:11-32.

5. Rocabado M. Biomechanical relationship of the cranial, cervical, and hyoid regions: A discussion. J Craniomandib Pract. 1983; 1(3):61-6. https://doi.org/10.1080/07345410.1983.11677834

6. Kitsoulis P, Marini A, Iliou K, Galani V, ZimpisA, Kanavaros $\mathrm{P}$, et al. Signs and symptoms of temporomandibular joint disorders related to the degree of mouth opening and hearing loss. BMC Ear, Nose Throat Disord. 2011; 11(1):1-8. https://doi.org/10.1186/1472-6815-11-5

7. Cesar Munhoz W, Pasqual Marques A. Body Posture Evaluations In Subjects with Internal Temporomandibular Joint Derangement. Cranio ${ }^{\circledR}$ [Internet]. 2009; 27(4):23142. Available from: http://www.tandfonline.com/doi/ full/10.1179/crn.2009.034 
8. Hong SW, Lee JK, Kang JH. Relationship among Cervical Spine Degeneration, Head and Neck postures, and Myofascial Pain in Masticatory and Cervical Muscles in Elderly with Temporomandibular Disorder. Arch Gerontol Geriatr [Internet]. 2019 https://doi.org/10.1016/j.archger.2018.12.004

9. Chaves TC, deAndrade e Silva TS, Monteiro SAC, Watanabe PCA, Oliveira AS, Grossi DB. Craniocervical posture and hyoid bone position in children with mild and moderate asthma and mouth breathing. Int J Pediatr Otorhinolaryngol. 2010; 74(9):1021-7.

https://doi.org/10.1016/j.ijporl.2010.05.031

10. Nicolakis P, Nicolakis M, Piehslinger E, Ebenbichler G, Vachuda M, Kirtley C, et al. Relationship between Craniomandibular Disorders and Poor Posture. Cranio. 2000; 18(2):106-12. https://doi.org/10.1080/08869634.2000.11746121

11. Sonnesen L, Bakke M, Solow B. Temporomandibular disorders in relation to craniofacial dimensions, head posture and bite force in children selected for orthodontic treatment. Eur J Orthod. 2001; 23(2):179-92.

https://doi.org/10.1093/ejo/23.2.179

12. Câmara-Souza MB, Figueredo OMC, Maia PRL, Dantas IS, BarbosaGAS.Cervicalpostureanalysisindentalstudentsand itscorrelationwithtemporomandibulardisorder.Cranio.2018 Mar; 36(2):85-90. doi: 10.1080/08869634.2017.1298226. Epub 2017 Mar 8. PMID: 28274183.

13. Matheus RA, Ramos-Perez FMDM, Menezes AV, Ambrosano GMB, Haiter-Neto F, Bóscolo FN, et al. The relationship between temporomandibular dysfunction and head and cervical posture. J Appl Oral Sci. 2009; 17(3):204-8. https://doi.org/10.1590/S1678-77572009000300014

14. Visscher CM, Lobbezoo F, de Boer W, van der Zaag J, Naeije M. Prevalence of cervical spinal pain in craniomandibular pain patients. Eur J Oral Sci [Internet]. 2001; 109(2):7680. Available from: http://www.ncbi.nlm.nih.gov/ pubmed/11347659.

https://doi.org/10.1034/j.1600-0722.2001.00996.x

15. Munhoz WC, Marques AP, Siqueira JTT de. Radiographic evaluation of cervical spine of subjects with temporomandibular joint internal disorder. Braz Oral Res [Internet]. 2004; 18(4):283-9. Available from: http:// www.scielo.br/scielo.php?script=sci_arttext\&pid=S1806$83242004000400002 \& \operatorname{lng}=$ en\&nrm=iso\&tlng=en.

https://doi.org/10.1590/S1806-83242004000400002

16. Zonnenberg AJJ, Van Maanen CJ, Oostendorp RAB, Elvers JWH. Body posture photographs as a diagnostic aid for musculoskeletal disorders related to temporomandibular disorders (TMD). Cranio. 1996; 14(3):225-32.

https://doi.org/10.1080/08869634.1996.11745972

17. Saito ET, Akashi PMH, de Camargo Neves Sacco I. Global BodyPostureEvaluationinPatientswithTemporomandibular Joint Disorder. Clinics (Sao Paulo). 2009; 64(1):35-9.
https://doi.org/10.1590/S1807-59322009000100007

18. Munhoz WC, Marques AP, De Siqueira JTT. Evaluation of body posture in individuals with internal temporomandibular joint derangement. Cranio. 2005; 23(4):269-77.

https://doi.org/10.1179/crn.2005.038

19. Munhoz WC, Marques AP. Body posture evaluations in subjects with internal temporomandibular joint derangement. Cranio - J Craniomandib Pract. 2009; 27(4):231-42. https://doi.org/10.1179/crn.2009.034

20. Rocha CP, Croci CS, Caria PHF. Is there relationship between temporomandibular disorders and head and cervical posture? A systematic review. J Oral Rehabil. 2013; 40(11):875-81. https://doi.org/10.1111/joor.12104

21. Faul F, Erdfelder E, Lang AG, Buchner A. G*Power 3: a flexible statistical power analysis program for the social, behavioral, and biomedical sciences. Behav Res Methods. 2007 May; 39(2):175-91. doi: 10.3758/bf03193146. PMID: 17695343.

22. Faul F, Erdfelder E, Buchner A, Lang AG. Statistical power analyses using $G^{*}$ Power 3.1: tests for correlation and regression analyses. Behav Res Methods. 2009 Nov; 41(4):1149-60. doi: 10.3758/BRM.41.4.1149. PMID: 19897823.

23. Souza JA, Pasinato F, Corrêa ECR, Maria A, Silva T. Global Body Posture and Plantar Pressure Distribution in Individuals With and Without Temporomandibular Disorder: A Preliminary Study. J Manipulative Physiol Ther [Internet]. 2014; 37(6):407-14. Available from: http://dx.doi. org/10.1016/j.jmpt.2014.04.003

24. Szucs KA, Brown EVD. Rater reliability and construct validity of a mobile application for posture analysis. J Phys Ther Sci. 2018; 30(1):31-6. https://doi.org/10.1589/jpts.30.31

25. Arnold CM, Beatty B, Harrison E, Olszynski W. The reliability of five clinical postural alignment measures for women with osteoporosis. Physiother Canada. 2000; 52(287294).

26. Hennessey L, Watson AW. Flexibility and posture assessment in relation to hamstring injury. $\mathrm{Br} \mathrm{J}$ Sports Med [Internet]. 1993; 27(4):243-6. Available from: http://www.pubmedcentral.nih.gov/articlerender. fcgi? artid $=1332012 \&$ tool $=$ pmcentrez\&rendertype $=$ abstract https://doi.org/10.1136/bjsm.27.4.243

27. Watson AWS, Mac Donncha C. A reliable technique for the assessment of posture: assessment criteria for aspects of posture. j Sport med phys fitnes. 2000; 40:260-70.

28. McRoberts LB, Cloud RM, Black CM. Evaluation of the New York Posture Rating Chart for Assessing Changes in Postural Alignment in a Garment Study. Cloth Text Res J. 2013; 31(2):81-96.

https://doi.org/10.1177/0887302X13480558

29. Steenks M, de Wijer A. Validity of the Research Diagnostic Criteria for Temporomandibular Disorders Axis I in clinical 
and research settings. J Orofac Pain. 2009; 23(1):9-16.

30. Mike TJ, Samuel FD, Lloyd A. Reliability of clinical temporomandibular disorder diagnoses.Pain. 2005; 118(12): 61-69.

https://doi.org/10.1016/j.pain.2005.07.018

31. Kurkcu M. (Translation in Turkish) Research Diagnostic Criteria for Temporomandibular Disorders. Journal of CraniomandibularDisorders:Facial\&OralPain,1992.http:// www.rdc-tmdinternational.org/TMDAssessmentDiagnosis/ RDCTMD/Translations/Turkish.aspx

32. Chaves TC, Turci AM, Pinheiro CF, Sousa LM, Grossi DB. Static body postural misalignment in individuals with temporomandibular disorders: Asystematic review. Brazilian J Phys Ther. 2014; 18(6):481-501. https://doi.org/10.1590/bjpt-rbf.2014.0061

33. Iunes DH, Carvalho LCF, Oliveira AS, BevilaquaGrossi D. Craniocervical posture analysis in patients with temporomandibular disorder. 2009; 13(1):89-95. https://doi.org/10.1590/S1413-35552009005000011

34. UritaniD,KawakamiT, InoueT,KiritaT.CharacteristicsofUpper Quadrant Posture of Young Women with Temporomandibular Disorders. J Phys Ther Sci [Internet]. 2014; 26(9):1469-
72. Available from:http://jlc.jst.go.jp/DN/JST.JSTAGE/ jpts/26.1469? lang $=$ en \&from $=$ CrossRef\&type $=$ abstract https://doi.org/10.1589/jpts.26.1469

35. Bakalkin G, Larygin K, Kobylianskiı̌ A, Samovilova N. Postural asymmetry induction by factors of the right and left hemispheres. Dokl Akad Nauk SSSR. 1981; 260(5):1271-5.

36. Previc FH. The relationship between eye dominance and head tilt in humans. Neuropsychologia. 1994; 32(10):1297303.

https://doi.org/10.1016/0028-3932(94)90111-2

37. Souza JA, Pasinato F, Corrêa ECR, Maria A, Silva T. Global Body Posture and Plantar Pressure Distribution in Individuals With and Without Temporomandibular Disorder: A Preliminary Study. J Manipulative Physiol Ther [Internet].2014; 37(6):407-14. Available from: http://dx.doi. org/10.1016/j.jmpt.2014.04.003

38. Bonato L, Quinelato V, De Felipe Cordeiro P, De Sousa E, Tesch R, Casado P. Association between temporomandibular disorders and pain in other regions of the body. J Oral Rehabil. 2016; 44(1):9-15. https://doi.org/10.1111/joor.12457 